YIJING YANG, Master ${ }^{1}$

E-mail: 18120934@bjtu.edu.cn

XU WU, Ph.D. ${ }^{1}$

(Corresponding author)

E-mail:wuxu@bjtu.edu.cn

HAONAN LI, Master. ${ }^{1}$

E-mail: 19120838@bjtu.edu.cn

${ }^{1}$ School of Traffic and Transportation

Beijing Jiaotong University

No.3, Shangyuan Village, Haidian District, Beijing,

China
Transport Logistics Original Scientific Paper Submitted: 9 May 2020 Accepted: 25 Aug. 2020

\title{
COLLABORATIVE OPTIMIZATION OF CAR-FLOW ORGANIZATION FOR FREIGHT TRAINS BASED ON ADJACENT TECHNICAL STATIONS
}

\begin{abstract}
This paper proposes a collaborative optimization model of car-flow organization for freight trains based on adjacent technical stations to minimize the average dwell time of train cars in a yard. To solve the car-flow organization problems, a priority-based hump sequence, which depends on the cars available in two adjacent technical stations, is adopted. Furthermore, a meta-heuristic algorithm based on the genetic algorithm and the taboo search algorithm is adopted to solve the model, and the introduction of the active scheduling method improves the efficiency of the algorithm. Finally, the model is applied to the car-flow organization problem of two adjacent technical stations, and the results are compared with those from a single technical station without collaboration. The results demonstrate that collaborative carflow organization between technical stations significantly reduces the average dwell time at the stations, thereby improving the utilization rate of railroad equipment. In addition, the results indicate that the hybrid genetic algorithm can rapidly determine the train hump and marshalling schemes.
\end{abstract}

\section{KEYWORDS}

collaborative optimization; car-flow organization; genetic algorithm; taboo search algorithm; active scheduling.

\section{INTRODUCTION}

At present, there are various railway freight organization modes used worldwide. A few countries in North America have abundant rail capacity. They have separate railway networks for freight traffic. The marshalling plan of North American freight trains is predominantly based on the unit trains at the departure station and the long-distance direct trains at the shunting yard [1]. However, rail capacity is limited in some regions, such as Europe and China. In these regions, freight and passenger trains use the same networks, and passenger transportation almost always takes precedence over freight transportation. When the number of cars is too small to organize direct transport, freight trains are formed by grouping cars with different origins and destinations to form new outbound trains at shunting yards. This shunting operation is very expensive and time-consuming. Bontekoning and Priemus [2] stated that, in Europe, shunting operations may require $10-50 \%$ of the train total transit time. In some countries, most railways consistently operate according to a specified schedule. When a freight train is reorganized at a technical station, the traffic continuum is scheduled. Thus, these systems do not require re-optimization of car-flow organization at the technical station. However, in China, there is no fixed schedule for freight trains, and there is no fixed traffic continuum, thereby increasing the complexity of the car-flow organization problem. Unreasonable car-flow organization will prolong the dwell time of freight trains at the technical station and may disrupt the schedule of the technical station, which can lead to increased operating costs for the whole hub. Optimizing the car-flow organization at a technical station can alleviate the pressure, improve the efficiency of car-flow organization, and reduce railway operating costs [3]. The existing studies are mostly limited to organization at a single technical station [4]. In reality, however, the operations of adjacent 
technical stations can affect each other, and collaborative operations between technical stations can facilitate minimization of the average dwell time of cars at the two yards. As such, extending the problem from a single technical station to two adjacent technical stations is necessary and valuable. This study thus investigates the collaborative optimization of the car-flow organization of freight trains at adjacent technical stations under some practical constraints.

\section{LITERATURE REVIEW}

This study investigates the problem of carflow organization of freight trains at the shunting yards. In this section, a mathematical description of the problem is provided along with a review of the modelling methods and algorithms used to approach this problem.

Research objective - In the car-flow organization problem, the regions with abundant capacity and high demand for train transportation mainly use the minimum cost as the objective function. Conversely, regions with limited capacity, where the number of cars and equipment capacity of a shunting yard is limited, use the minimum dwell time of cars at the station as the objective function [6]. Yaghini [4] proposed a railway blocking model with fuzzy travel costs for railway freight costs and transformed it into a classic railway blocking model. The results showed that the method could significantly reduce the costs of transporting goods. Beloevi [5] studied the reorganization of freight trains at technical stations and trains marshalling methods, and according to the scale of the complexity of different grouping tasks, the rational application of the elementary grouping plan, triangle grouping plan and geometric grouping plan was proposed. Although [4-5] have achieved promising results, their studies were conducted at a single technical station, and the cooperation between technical stations was neglected. This may have prevented the car-flow organization of railway freight trains from being optimized at the railway network level and increased the total cost of railway freight transportation.

Model design - The modelling methods used to solve the freight train car-flow organization problem are mainly divided into the network-flows method and the mathematical programming method. The network-flows method effectively solves small-scale problems, but it becomes overly complex in the modelling of large-scale problems [7]. The mathematical programming method can be further divided based on the decision variables into the $0-1$ programming model and the mixed-integer programming model. The $0-1$ programming model can be solved using the sequential combination tree method for small-scale problems, but it cannot handle large-scale problems [8]. Yaghini [9] constructed a mixed integer programming model of railway marshalling by taking the lowest rail transportation cost as the objective function and considering the constraints of car-flow balance and the number of cars that can be reclassified. Calado [10] was to analyse the problem related to the allocation of the cars and developed a mixed integer programming model that proposed optimal scheduling of the cars by considering the capacity of yards and operating costs. This model is more suitable than others to accurately describe the freight train car-flow organization problem.

Solving algorithms - In earlier studies, traditional solution methods, such as the analytical calculation method and the branch and bound method, were often used to solve the car-flow organization problem. These traditional solution methods are easy to calculate and can provide accurate solutions. However, as car-flow increases and the structure of the railway network becomes more complex, the speed, accuracy, and reliability of traditional solution methods cannot be guaranteed [11].

In recent research, meta-heuristic algorithmssuch as the genetic algorithm, simulated annealing algorithm, and taboo search algorithm - have been widely used in solving the car-flow organization problem and have exhibited better performance than traditional solution methods. The genetic algorithm is widely used in this field [12]. However, due to its inherent limitations, it is easy to fall into the local optimal solution, which limits the application of the algorithm to the solution of complex problems. The taboo search and simulated annealing algorithms are both local intelligent search algorithms. Both expand the optimization range through different methods and have better global search capabilities than the genetic algorithm. The taboo search algorithm can search beyond the local optimal solution by setting taboo tables and amnesty criteria. Schindl [13] used a taboo search algorithm to solve the models built for truck allocation problems, but its optimization results 
depended on the quality of the initial solution. Shafia [14] used fuzzy methods to weigh the total train delay, robustness of train operation and outbound time interval, and subsequently used the simulated annealing algorithm to solve the car-flow organization problem. However, the simulated annealing algorithm may return to the previous solution and subsequently linger around the local optimal solution, increasing the overall calculation time. Moreover, Liu [15] referred to workpiece sequencing methods where multiple trains need to occupy the same line section simultaneously to minimize the overall running time of the train. Lange [16] aimed to minimize total tardiness of all trains at their destinations by transforming the train scheduling problem into a workpiece scheduling problem where the workpiece represented the train and the machine represented tracks and established a corresponding model to solve the problem. This paper outlines the construction of a hybrid genetic algorithm based on the genetic algorithm and the taboo search algorithm to compensate for their respective shortcomings. Furthermore, the idea of workpiece sequencing is integrated into the hybrid genetic algorithm to improve its accuracy and efficiency.

The remainder of the paper is organized as follows. Section 3 describes the operational processes that are executed at two adjacent freight shunting yards and constructs a collaborative optimization model for freight train car-flow organization. In Section 4 the problem is modelled by a dynamic, stochastic process that approaches the actual situation, and algorithm analysis is provided. To validate the model, a case study is described, and the test results of the solution are presented in Section 5. Finally, the concluding remarks are presented in Section 6.

\section{PROBLEM DESCRIPTION AND MODEL DESIGN}

\subsection{Collaborative optimization}

In railway transportation systems, the technical stations are important nodes and hubs, and they are the basic units of the system. As the operations between technical stations of the railway network are interrelated, the car-flow organization of freight trains at a technical station affects the efficiency and effectiveness of both the current and adjacent technical stations. To improve the efficiency of rail freight transportation, it is therefore necessary to investigate the cooperative operations between technical stations. The assumed position of the stations is shown in Figure 1 where the forward arrow represents the running direction of the train.

The adjacent technical stations $\mathrm{B}$ and $\mathrm{C}$ are selected as the subject of this research, and they both have cars of block H. It can be seen from Figure 1 that the car-flow routing from station $\mathrm{B}$ to $\mathrm{H}$ coincides partially with that from station $\mathrm{C}$ to $\mathrm{H}$. As such, the cars of block $\mathrm{H}$ from station $\mathrm{B}$ can be merged into the trains from station $\mathrm{B}$ to $\mathrm{C}$ and then merged into the trains from station $\mathrm{C}$ to $\mathrm{H}$. The freight train formation plan for a certain stage is affected by the cars on hand and the inbound trains in this stage. If trains from technical station $\mathrm{C}$ to station $\mathrm{H}$ fail to meet the outbound train criteria, and during the stage there are no cars arriving at station $\mathrm{H}$, the dwell time of these cars at technical station $\mathrm{C}$ will be prolonged. If the appropriate cars in station $\mathrm{B}$ are provided to technical station $\mathrm{C}$ during the effective time period, the average dwell time of the cars at stations $\mathrm{B}$ and $\mathrm{C}$ will be reduced.

The above analysis demonstrates that the carflow organization operations between adjacent technical stations are interrelated. Through the

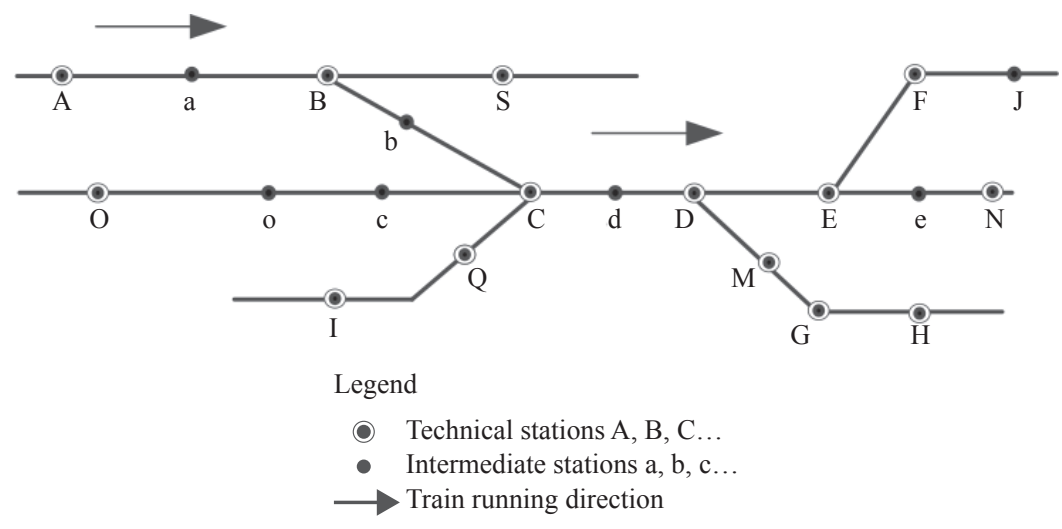

Figure 1 - Schematic presentation of the technical stations 
collaborative operation of freight trains between technical stations, the average dwell time of cars at the two technical stations could be effectively reduced, and the utilization rate of the railway lines at the station could be improved.

\subsection{Reference and application of active scheduling}

In collaborative optimization of car-flow organization for freight trains at adjacent technical stations, each train that needs to be reclassified must undergo multiple operations. Each operation is completed at a specific location and requires the completion of the operation preceding it. The operation can be completed for only one train at any given time and cannot be interrupted. Over time, the trains that require reclassification will be operated in a certain sequence to minimize the dwell time of the cars. It can thus be seen that collaborative optimization of the car-flow organization is similar to traditional workpiece sequencing problems.

Accordingly, the active scheduling method from workpiece sequencing is referenced and integrated into the hybrid genetic algorithm. The introduction of the active scheduling method could reduce the operation time of trains by scheduling the trains in a shorter time. Taking the train marshalling operation data shown in Table 1 as an example, the marshalling operation time is $15 \mathrm{~min}$. According to the marshalling sequence and the car-flow origins of outbound trains, the earliest start time for each train marshalling operation can be determined. Based on the marshalling sequence of outbound trains, the operation process shown in Figure 2 is obtained. However, the earliest start time of the marshalling operation M2 for Train 2002 is earlier than the earliest start time of the marshalling operation M1 for Train 2001. As the train marshalling operation time is $15 \mathrm{~min}, \mathrm{M} 2$ can be inserted before M1 without affecting M1. Similarly, the marshalling operation M4 can be inserted before M3, as shown in Figure 3. The end time of the total adjusted operation is $11: 15$, which is $15 \mathrm{~min}$ earlier than the original operation sequence.

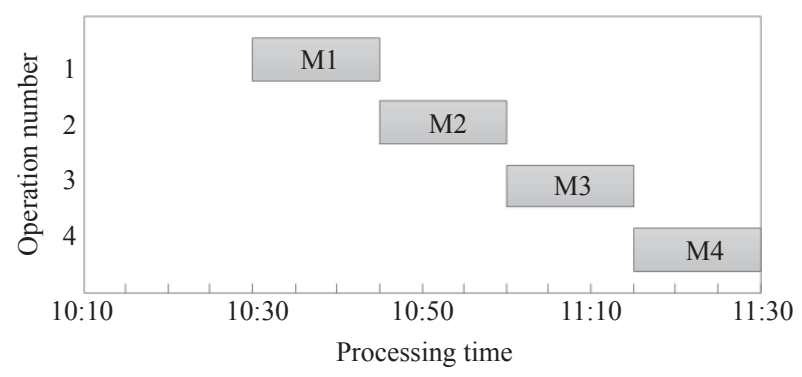

Figure 2-Gant chart of marshalling operation based on outbound train sequences

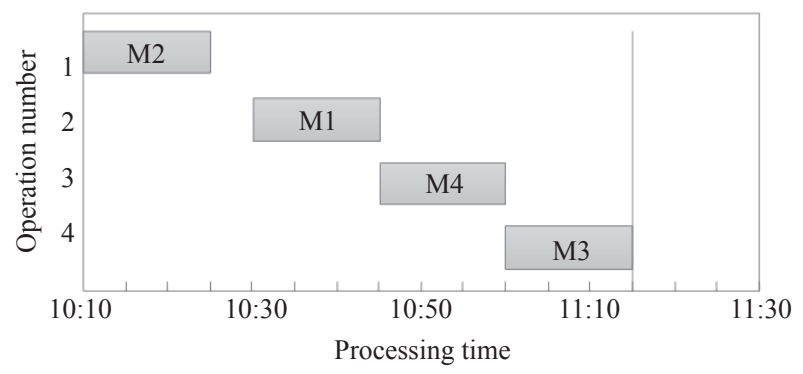

Figure 3 - Gantt chart of marshalling after implementation of active scheduling

\subsection{Construction of a model}

When the adjacent technical stations B and C collaborate, technical station $\mathrm{B}$ can provide technical station $\mathrm{C}$ with a number of cars of a certain block. A collaborative optimization model for carflow organization can then be built to optimize the freight train formation plans of stations B and C. As the organization of car-flow in the technical

Table 1 - Sample data for inbound and outbound trains

\begin{tabular}{||c|c|c|c|c|c|c||}
\hline $\begin{array}{c}\text { Inbound } \\
\text { Train \# }\end{array}$ & $\begin{array}{c}\text { Inbound train marshalling } \\
\text { formations }\end{array}$ & $\begin{array}{c}\text { Completion } \\
\text { time of break- } \\
\text { up operation }\end{array}$ & $\begin{array}{c}\text { Outbound } \\
\text { train } \#\end{array}$ & $\begin{array}{c}\text { Marshalling } \\
\text { order }\end{array}$ & $\begin{array}{c}\text { Car-flow origins and } \\
\text { marshalling formation of } \\
\text { outbound trains }\end{array}$ & $\begin{array}{c}\text { Start time of } \\
\text { marshalling } \\
\text { operation }\end{array}$ \\
\hline \hline 1001 & $\mathrm{~A} / 20, \mathrm{~B} / 15, \mathrm{C} / 25, \mathrm{D} / 5$ & $10: 10$ & 2001 & 1 & $1001 / \mathrm{A} / 20,1002 / \mathrm{A} 15$ & $10: 30$ \\
\hline 1002 & $\mathrm{~A} / 15, \mathrm{~B} / 30, \mathrm{C} / 2, \mathrm{D} / 7$ & $10: 30$ & 2002 & 2 & $1001 / \mathrm{B} / 10,1001 / \mathrm{C} / 25$ & $10: 10$ \\
\hline 1003 & $\mathrm{~A} / 15, \mathrm{~B} / 4, \mathrm{C} / 15, \mathrm{D} / 20$ & $10: 45$ & 2003 & 3 & $\begin{array}{c}1001 / \mathrm{D} / 5,1002 / \mathrm{D} / 7, \\
1003 / \mathrm{D} / 20,1004 / \mathrm{D} / 3\end{array}$ & $11: 00$ \\
\hline 1004 & $\mathrm{~A} / 16, \mathrm{~B} / 14, \mathrm{C} / 10, \mathrm{D} / 10$ & $11: 00$ & 2004 & 4 & $1002 / \mathrm{B} / 30,1002 / \mathrm{C} / 2$, & $10: 45$ \\
\hline
\end{tabular}

*letter indicates the direction of the car-flow, the number after the letter indicates the number of cars of this direction. 
stations is relatively complex, to simplify the carflow organization operation, some uncertain factors are converted into certain factors for this analysis. The relevant assumptions are as follows:

1) The train arrives on time according to the schedule and the departure criterion is that the number of cars reaches the required number.

2) The marshalling yard has one hump, one rolling track of hump, and the equipment and marshalling yard capacity in the technical stations meet the needs of the operation of the car-flow organization. The single push and slip method is adopted, and the shunting locomotive can be used at the beginning of the plan.

3) The shunting locomotive can only complete the break-up or marshalling operation of one train at any given time, meaning that the train can only be operated by one shunting locomotive. Once the operation begins it cannot be stopped part way through.

The objective function of the collaborative optimization model for freight train car-flow organization of adjacent technical stations is the minimum dwell time of cars in the yard. Thus,

$$
\left\{\begin{array}{l}
\min T=\frac{T_{B} \sum_{k=1}^{K} N_{B i k}+T_{C} \sum_{k=1}^{K} N_{C i k}}{\sum_{k=1}^{K} N_{B i k}+\sum_{k=1}^{K} N_{C i k}} \\
T_{B}=\frac{\sum_{j=1}^{n} \sum_{i=1}^{m} \sum_{k=1}^{K} x_{B j i k}\left(t d_{B j}-t a_{B i}\right)+\sum_{i=1}^{m}\left[\left(\sum_{k=1}^{K} N_{B i k}-\sum_{j=1}^{n} \sum_{k=1}^{K} x_{B j i k}\right)\left(t B_{B o}-t a_{B i}\right)\right]}{\sum_{k=1}^{K} N_{B i k}(1)} \\
T_{C}=\frac{\sum_{j=1}^{n} \sum_{i=1}^{m} \sum_{k=1}^{K} x_{C i j k}\left(t d_{C j}-t a_{C i}\right)+\sum_{i=1}^{m}\left[\left(\sum_{k=1}^{K} N_{C i k}-\sum_{j=1}^{n} \sum_{k=1}^{K} x_{C i j k}\right)\left(t t_{C o}-t a_{C i}\right)\right]}{\sum_{k=1}^{K} N_{C i k}}
\end{array}\right.
$$

where $T$ indicates the average dwell time of cars at stations $\mathrm{B}$ and $\mathrm{C}$, and $T_{B}$ and $T_{C}$ represent the average time of cars at technical stations $\mathrm{B}$ and $\mathrm{C}$, respectively. $x_{i j k}$ indicates the number of cars of block $k$ provided by the inbound train $i$ to the outbound train $j ; x_{B i j k}$ indicates the number of cars of block $k$ provided by the inbound train $i$ to the outbound train $j$ at station $\mathrm{B} ; x_{C i j k}$ indicates the number of cars of block $k$ provided by the inbound train $i$ to the outbound train $j$ at station $\mathrm{C}$; and $x_{B i j k}$ and $x_{C i j k}$ are, respectively, a form of $x_{i j k}\left(x_{B i j k} \in x_{i j k}\right.$, $\left.x_{C i j k} \in x_{i j k}\right) ; t d_{j}$ is the departure time of the outbound train $j ; t d_{B j}$ indicates the departure time of the outbound train $j$ at station $\mathrm{B}$; and $t d_{C j}$ indicates the departure time of the outbound train $j$ at station $\mathrm{C}\left(t d_{B j} \in t d_{j}, t d_{C j} \in t d_{j}\right)$. Similarly, in the following variable definitions, when it is necessary to distinguish the technical station, subscripts $\mathrm{B}$ and $\mathrm{C}$ are used as appropriate; $t a_{i}$ is the inbound time of the inbound train $i, t_{o}$ is the end time of the study period, and $N_{i k}$ is the number of cars of block $k$ in the marshalling formation of inbound train $i$ (where, $i=1,2, \ldots, m ; k=1,2, \ldots, K)$.

There are $m$ inbound freight trains and $n$ outbound freight trains during the stage. The humping sequence of the inbound trains is $S_{1}, S_{2}, \ldots, S_{h}, \ldots, S_{m}$, where $S_{1}, S_{2}, \ldots, S_{h}, \ldots, S_{m}$ is the arrangement of trains with arrival orders $1,2, \ldots, m$. The marshalling sequence of the outbound trains is $R_{1}, R_{2}, \ldots, R_{l}, \ldots, R_{n}$, where $R_{1}, R_{2}, \ldots, R_{l}, \ldots, R_{n}$ is an arrangement of outbound trains with departing orders $1,2, \ldots, n$.

The Constraints 2-11, outlined below, apply to both stations B and C. The constraints on arrival and break-up operations are as follows. In Equations 2-4, $t b s_{s h}^{(\text {early) }}$ denotes the earliest start time of the breakup operation with a humping sequence of inbound trains denoted by $S_{h}$. The actual start time of the break-up of the train is $t b s_{s h} ; t b f_{s_{h}}$ denotes the end time of the break-up operation of the inbound train with the order $S_{h}$; TA is the arriving technical operation time of the trains; and $T B$ is the time of the break-up operation of the inbound train. Therefore,

$t b s_{s_{h}}^{(e a r l y)}=t a_{S_{h}}+T A$

$t b s_{s h}= \begin{cases}t b s_{s h}^{(\text {early })} & (h=1) \\ \max \left\{t b f_{s h-1}, t b s_{s h}^{(\text {early })}\right\} & (h=2,3, \ldots, m)\end{cases}$

$t b f_{s h}=t b s_{s h}+T B$

Equation 2 indicates that the earliest start time of the break-up operation for an inbound train is the end time of the inbound train technical operation. Equations 3 and 4 indicate the actual start and end times of the break-up operation for an inbound train, respectively.

The constraints on marshalling and departure operations are outlined in Equations 5-8, where $\operatorname{tms}_{R l}^{(\text {early })}$ indicates the earliest start time of the marshalling operation of outbound train $R_{l} ; \mathrm{tms}_{R_{l}}$ and $t m f_{R_{l}}$ indicate the actual start and end time of the marshalling operation of outbound train $R_{l}$, respectively; $x_{S h R l}^{(k)}$ is a variable of 0 or 1 such that when inbound trains with the break-up sequence $S_{h}$ provide the cars for the outbound train $R_{l}, x_{S_{h} R_{l}}^{(k)}=1$; otherwise, $x_{S h R l}^{(k)}=0$. Finally, $T M$ is the train marshalling operation time, $T D$ is the outbound technical operation time and $\mathrm{M}$ is positive infinity. Then,

$$
t m s_{R l}^{(e a r l y)}=\max \left\{t b f_{s h} \cdot x_{S_{h j}}^{(k)}\right\}+M\left(1-x_{S_{h j}}^{(k)}\right) \quad(h=1,2, \ldots, m)
$$


$t m s_{R l}= \begin{cases}t m s_{R l}^{(e a r l y)} & (l=1) \\ \max \left\{t m f_{R l-1}, t m s_{R l}^{(\text {early })}\right\} & (l=2,3, \ldots, n)\end{cases}$

$t m f_{R l}=t m s_{R l}+T M$

$t d_{R l}=t m f_{R l}+T D$

Equation 5 indicates that the earliest start time of the marshalling operation for an outbound train depends on the end time of the break-up operation of the inbound train providing the cars. Equation 6 indicates the actual start time of the marshalling operation for an outbound train. Equation 7 indicates the end time of the marshalling operation for an outbound train. Finally, Equation 8 indicates the departure time of the outbound train.

The constraint of car-flow connection time is provided by

$$
t m s_{R_{l}}-t b f_{S_{h}} \geq M\left(x_{S h R l}^{(k)}-1\right)
$$

Equation 9 indicates that the start time of the marshalling operation for an outbound train must be later than the end time of the break-up operation of the train providing the cars.

The constraint of the departure criteria for outbound trains is provided by Equation 10, where $V$ indicates the number of cars required for an outbound train reaching the departure criteria; $k_{j}$ represents the block included in the marshalling of the outbound train; and $j=1,2, \ldots, n ; k_{j}=1,2, \ldots, K$.

$V=\sum_{i=0}^{m} \sum_{k \in k_{j}} x_{i j k}$

Equation 10 indicates that the number of cars of the outbound train $j$ must reach $V$ for the outbound train to be considered as having reached the departure criteria.

The constraint of the marshalling formation is provided by

$\sum_{j=1}^{n+1} x_{i j k} \leq N_{i k}$

Equation 11 indicates that the sum of the number of cars of block $k$ provided by the inbound train $i$ for the outbound train $j$ cannot exceed the number of cars contained by block $k$.

The constraints on collaborative optimization for car-flow organization are provided by Equations 12-14. $N_{B i k^{\prime}}$ indicates the number of cars of block $k^{\prime}$ for inbound train $i$ at station B. $N_{C_{j}}^{\left(k^{\prime}\right)}$ indicates the number of cars of block $k^{\prime}$ for outbound train $j$ at station C. $N_{B j}^{\left(C k^{\prime}\right)}$ is the number of cars for block $k^{\prime}$ of outbound train $j$ that moves from station B to station $\mathrm{C}$ during this stage. $N_{C i k}$ indicates the number of cars for block $k^{\prime}$ of inbound train $i$ that arrives at station $\mathrm{C}$ during the stage.

$$
\begin{aligned}
& V>\sum_{i=1}^{m} N_{B i k^{\prime}}>0 \\
& V>N_{C_{j}}^{\left(k^{\prime}\right)}>0 \\
& \sum_{j=1}^{n} N_{B_{j}}^{\left(C_{k}^{\prime}\right)}=\sum_{i=1}^{m} N_{C i k^{\prime}}
\end{aligned}
$$

Equations 12-13 are the prerequisite constraints for coordinated operations of adjacent technical stations. Equation 12 indicates that technical station B has a certain number of remaining cars of block $k^{\prime}$. Equation 13 indicates that the number of cars in block $k^{\prime}$ of outbound train $j$ cannot reach the departure criteria at technical station C. Equation 14 is a car-flow balance constraint.

\section{PROCESS AND ALGORITHM ANALYSIS}

The process of collaborative optimization for freight train car-flow organization for two adjacent technical stations is as follows. First, according to the formation plan of technical stations $\mathrm{B}$ and $\mathrm{C}$, the status of outbound trains from each station and the remaining cars can be determined. Second, it can be determined whether it is necessary for technical station $\mathrm{B}$ to provide cars to station $\mathrm{C}$ to ensure that the trains from station $\mathrm{C}$ reach the departure criteria. The time period for station $B$ to provide the cars can also be determined. Third, if the adjacent technical stations need to collaborate, the train bound for station $\mathrm{C}$ needs to adjust the car flow; that is, the cars of block $\mathrm{k}$ that need to be provided to station $\mathrm{C}$ must be merged into it. Finally, the car-flow organization of the two technical stations can be optimized with the goal of minimizing the car average dwell time at stations $\mathrm{B}$ and $\mathrm{C}$.

The car-flow organization of freight trains is a typical discrete problem. Among many heuristic algorithms, the genetic algorithm uses biological evolution as the prototype and follows the rule of "survival of the fittest." By calculating the fitness value, individuals with high fitness values are selected, and individuals with low fitness values are eliminated. This algorithm is suitable for solving discrete problems, it is highly robust, and has good operability. The optimization result is not affected by the initial value, but the algorithm can easily fall into a local optimum by continuously optimizing the local expansion to the global solution. The 
taboo search algorithm intentionally avoids local optimal solutions by setting taboo tables and amnesty criteria. As such, this study used a hybrid genetic algorithm that is a mixture of the genetic algorithm and the taboo search algorithm to solve the model, thus improving the optimization performance and the quality of the algorithm.

When the adjacent technical stations $\mathrm{B}$ and $\mathrm{C}$ collaborate, in order to make the collaborative train of technical station B better cooperate with the distribution operation of technical station $\mathrm{C}$, the collaborative train in technical station $\mathrm{B}$ is assigned a certain priority for marshalling and departure. When optimizing the model through the algorithm, the data of technical stations B and C are first imported into the algorithm, and priority is given to the trains that provide cars to station C. This priority is specifically expressed as follows: when other trains conflict with the trains providing cars in marshalling operations, the trains providing cars are given priority.

In the hybrid genetic algorithm, the minimum dwell time of the cars at the two technical stations is the optimization goal. The organization of the car-flow of technical station B is processed first and the result is recorded. After obtaining the results of technical station B, the car-flow information of the trains providing cars is imported into the data of technical station $\mathrm{C}$, and the plan of car-flow organization can be obtained for technical station $\mathrm{C}$. Finally, the average dwell time of the cars of the two technical stations is optimized, and the optimal plan can be obtained. The flow chart of the hybrid genetic algorithm is shown in Figure 4. The main steps of the hybrid genetic algorithm are described below.

1) The hump sequence is converted into a genetic sequence by coding, which constitutes a chromosome. Using decimal coding, the chromosome length is the sum of the number of inbound trains $m$ and the number of outbound trains $n$. The arrangement of the first $m$ genes of the chromosome is represented by the humping sequence of inbound trains. The arrangement of the last $n$ genes of the chromosome represents the assembly sequence of outbound trains. Furthermore, let $C_{T S}=0$, where $C_{T S}$ is used to record the number of iterations of the hybrid genetic algorithm.

2) Let $C_{G A}=0$, where $C_{G A}$ is used to record the number of cycles of the genetic algorithm in the hybrid genetic algorithm. The inbound and outbound train information is read to generate an initial solution. The origins of the outbound train car-flow can be determined based on the outbound train marshalling formation and the end time of

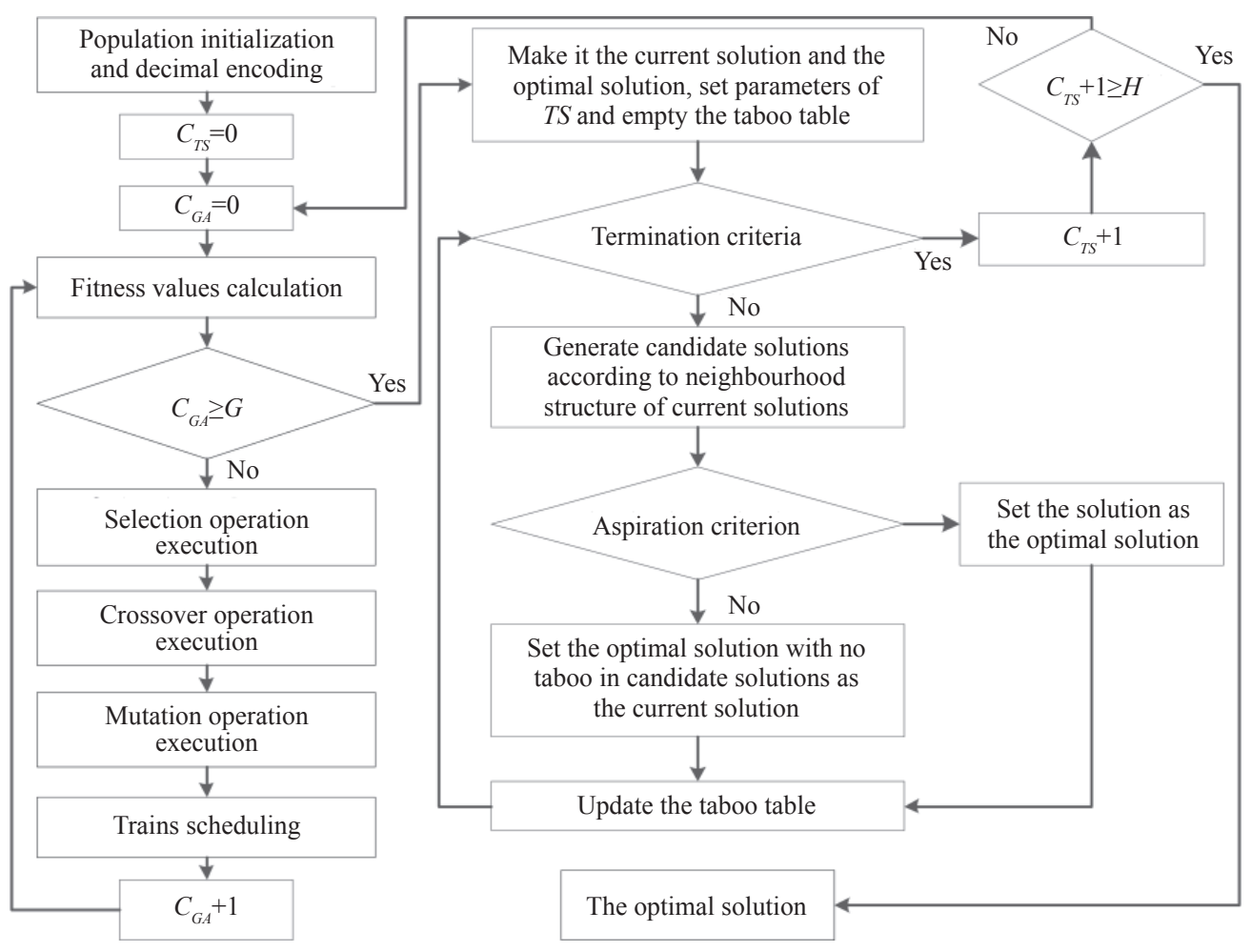

Figure 4 - Flow chart of the hybrid genetic algorithm 
the inbound train break-up operation and marshalling operations. This confirms whether the outbound trains satisfy the departure criteria and defines the dwell time of the cars as the fitness value of the algorithm. The lower the dwell time at the station, the greater the fitness value.

3) Two chromosomes are selected with probability $p_{c}$, and the Partial-Mapped Crossover (PMX) operator is used to perform the crossover operation of the first $m$ genes and the last $n$ genes of the chromosomes, separately. The mutation chromosomes are selected with probability $p_{m}$ to complete the mutation operation of the first $m$ genes and the last $n$ genes, separately. On this basis, active scheduling is used to dispatch trains, and the optimized hump sequence can be obtained. When the number of iterations reaches the set maximum, the algorithm stops.

4) The optimal solution obtained by the genetic algorithm described in steps 1-3 is used as the initial solution and is set as the current solution and the optimal solution.

5) A set of solutions to be selected is obtained according to the neighbourhood structure of the initial solution, and the taboo of each candidate solution is confirmed. The N7 neighbourhood structure proposed by Zhang [17] is used as it can ensure that a feasible solution is generated, a wider solution space can be explored, and a higher quality, feasible schedule can be obtained.

6) The amnesty criterion is confirmed. If the fitness of the taboo solution is higher than that of any previous solution, the amnesty criterion is met, the solution is banned, and the current and optimal solutions are updated to this solution. Otherwise, the most adaptive solution from the non-taboo solution set is selected as the current solution, and the taboo table is updated.

7) Steps 2-6 are repeated until the algorithm end criteria are met. The algorithm end criteria are generally set to the maximum number of iterations of the algorithm.

\section{CASE STUDY}

\subsection{Parameters}

The hybrid genetic algorithm is used to solve the following instance using MATLAB(2016Ra) [18]. The genetic algorithm parameters are designed as follows: population size $=200$, maximum number of iterations $=300$, crossover probability $=0.8$, and mutation probability $=0.05$. With regards to the taboo search algorithm parameters, the length of the taboo table is $\mathrm{L}=0$, as experimental and comparative analyses show that the optimization effect behaves well when $\mathrm{L}=20$. A 4GB RAM and Intel $2.20 \mathrm{GHz}$ computing environment is used to validate the algorithm and solve the model. The parameters of this example case are as follows: the inbound and outbound train technical inspection operation time is 30 min. The break-up operation time is $30 \mathrm{~min}$, and the time required to complete a freight train marshalling operation at a technical station is $15 \mathrm{~min}$. The departure criteria for the outbound train is that there are at least 50 cars, and that the outbound time is specified according to the real-time operation. The distance between the two adjacent technical stations is $80 \mathrm{~km}$, and the speed of the freight trains is $80 \mathrm{~km} / \mathrm{h}$.

\subsection{Results}

Based on the car-flow organization for freight trains at a single technical station, the plan for the break-up operation of the inbound train at technical station B is obtained through the hybrid genetic algorithm. This plan is shown in Table 2. The outbound train marshalling plan is shown in Table 3. The average dwell time of the cars at technical station B is 262.96 $\mathrm{min}$, and the number of trains reaching the departure criteria is 9. The break-up plan of the inbound train at technical station $\mathrm{C}$ is shown in Table 4, and the outbound train marshalling plan is shown in Table 5. The average dwell time of the cars at technical station $\mathrm{C}$ is $246.01 \mathrm{~min}$, and the number of trains reaching the departure criteria is 10 . The simulation results of the average dwell time of the cars at technical stations $\mathrm{B}$ and $\mathrm{C}$ based on the hybrid genetic algorithm are shown in Figure 5.

The collaborative optimization model for the freight train car-flow organization proposed in this paper is applied to the above instance to validate the collaborative optimization approach. The car-flow adjustment of technical station B after a collaborative organization is shown in Table 6. The average dwell time of the cars at technical station B is 258.31 min, and the number of trains reaching the departure criteria is 10 . The additional outbound train reaching the departure criteria is Train 20008, which is composed of 9 cars from Train 10004, 27 cars from Train 10006 and 14 cars from Train 10008. The outbound time of train 20008 at technical station B is 16:04 and its arrival time at technical station $\mathrm{C}$ is 17:04. The changed outbound train marshalling plan for 
$\underline{\text { Yang Y, Wu X, Li H. Collaborative Optimization of Car-flow Organization for Freight Trains Based on Adjacent Technical Stations }}$

Table 2 - Break-up plan of inbound trains at technical station B

\begin{tabular}{||c|c|c|c|c|c|c|c||}
\hline $\begin{array}{c}\text { Inbound } \\
\text { train \# }\end{array}$ & $\begin{array}{c}\text { Inbound } \\
\text { time }\end{array}$ & $\begin{array}{c}\text { End time } \\
\text { of inbound } \\
\text { operation }\end{array}$ & Marshalling formation & $\begin{array}{c}\text { Break-up } \\
\text { order }\end{array}$ & $\begin{array}{c}\text { Start time } \\
\text { of break-up } \\
\text { operation }\end{array}$ & $\begin{array}{c}\text { End time } \\
\text { of break-up } \\
\text { operation }\end{array}$ & $\begin{array}{c}\text { Average } \\
\text { dwell time of } \\
\text { cars [min] }\end{array}$ \\
\hline \hline 10001 & $8: 45$ & $9: 15$ & $\mathrm{~A} / 30, \mathrm{G} / 15, \mathrm{D} / 12$ & 1 & $9: 15$ & $9: 45$ & \\
\hline 10002 & $9: 10$ & $9: 40$ & $\mathrm{~F} / 30, \mathrm{E} / 15, \mathrm{D} / 7$ & 2 & $9: 45$ & $10: 15$ \\
\hline 10003 & $9: 30$ & $10: 00$ & $\mathrm{M} / 19, \mathrm{G} / 18, \mathrm{E} / 5$ & 3 & $10: 15$ & $10: 45$ \\
\hline 10004 & $10: 12$ & $10: 42$ & $\mathrm{~F} / 24, \mathrm{E} / 13, \mathrm{C} / 9$ & 5 & $11: 20$ & $11: 50$ \\
\hline 10005 & $10: 20$ & $10: 50$ & $\mathrm{~A} / 28, \mathrm{G} / 15$ & 4 & $10: 50$ & $11: 20$ \\
\hline 10006 & $10: 58$ & $11: 28$ & $\mathrm{H} / 18, \mathrm{D} / 19, \mathrm{C} / 17$ & 11 & $14: 34$ & $15: 04$ \\
\hline 10007 & $11: 25$ & $11: 55$ & $\mathrm{~A} / 14, \mathrm{E} / 14, \mathrm{~F} / 21, \mathrm{O} / 10$ & 6 & $11: 55$ & $12: 25$ \\
\hline 10008 & $11: 46$ & $12: 16$ & $\mathrm{M} / 15, \mathrm{G} / 16, \mathrm{H} / 14$ & 8 & $13: 04$ & $13: 34$ \\
\hline 10009 & $12: 04$ & $12: 34$ & $\mathrm{~A} / 28, \mathrm{M} / 2, \mathrm{G} / 14, \mathrm{Q} / 10$ & 7 & $12: 34$ & $13: 04$ \\
\hline 10010 & $12: 08$ & $12: 38$ & $\mathrm{E} / 10, \mathrm{~F} / 17, \mathrm{D} / 17$ & 12 & $15: 04$ & $15: 34$ \\
\hline 10011 & $12: 10$ & $12: 40$ & $\mathrm{~F} / 20, \mathrm{M} / 12, \mathrm{G} / 15, \mathrm{D} / 12$ & 9 & $13: 34$ & $14: 04$ \\
\hline 10012 & $12: 15$ & $12: 45$ & $\mathrm{Q} / 20, \mathrm{M} / 9, \mathrm{~F} / 8, \mathrm{E} / 10$ & 10 & $14: 04$ & $14: 34$ & \\
\hline
\end{tabular}

Table 3 - Marshalling plans for trains departing from technical station B

\begin{tabular}{|c|c|c|c|c|c|c|}
\hline $\begin{array}{l}\text { Outbound } \\
\text { train \# }\end{array}$ & Marshalling formation & $\begin{array}{l}\text { Marshalling } \\
\text { order }\end{array}$ & $\begin{array}{l}\text { Operating } \\
\text { time }\end{array}$ & $\begin{array}{c}\begin{array}{c}\text { Start time of } \\
\text { marshalling } \\
\text { operation }\end{array} \\
\end{array}$ & $\begin{array}{c}\text { End time of } \\
\text { marshalling } \\
\text { operation }\end{array}$ & $\begin{array}{l}\text { Outbound } \\
\text { time }\end{array}$ \\
\hline 20001 & $10004 / \mathrm{E} / 13,10004 / \mathrm{F} / 24,10007 / \mathrm{E} / 13$ & 4 & 15 & $12: 25$ & $12: 40$ & $13: 10$ \\
\hline 20002 & $10005 / \mathrm{A} / 8,10007 / \mathrm{A} / 14,10009 / \mathrm{A} / 28$ & 5 & 15 & $13: 04$ & $13: 19$ & $13: 49$ \\
\hline 20003 & $10001 / \mathrm{G} / 15,10003 / \mathrm{M} / 19,10003 / \mathrm{G} / 16$ & 1 & 15 & $10: 45$ & 11:00 & $11: 30$ \\
\hline 20004 & $\begin{array}{c}10001 / \mathrm{D} / 12,10002 / \mathrm{D} / 7,10006 / \mathrm{D} / 19 \\
10011 / \mathrm{D} / 12\end{array}$ & 9 & 15 & $15: 04$ & $15: 19$ & $15: 49$ \\
\hline 20005 & $10002 / \mathrm{E} / 15,10002 / \mathrm{F} / 30,10003 / \mathrm{E} / 5$ & 2 & 15 & $11: 00$ & $11: 15$ & $11: 45$ \\
\hline 20006 & $\begin{array}{c}10009 / \mathrm{G} / 14,10011 / \mathrm{M} / 12,10011 / \\
\mathrm{G} / 15,10012 / \mathrm{M} / 9\end{array}$ & 7 & 15 & $14: 34$ & $14: 49$ & $15: 19$ \\
\hline 20007 & $\begin{array}{c}10007 / \mathrm{E} / 1,10007 / \mathrm{F} / 21 \\
10011 / \mathrm{F} / 20,10012 / \mathrm{E} / 8\end{array}$ & 8 & 15 & $14: 49$ & $15: 04$ & $15: 34$ \\
\hline 20008 & C/Outage & - & - & - & - & - \\
\hline 20009 & $\mathrm{O} /$ Outage & - & - & - & - & - \\
\hline 20010 & Q/Outage & - & - & - & - & - \\
\hline 20011 & $10001 / \mathrm{A} / 30,10005 / \mathrm{A} / 20$ & 3 & 15 & $11: 20$ & $11: 35$ & $12: 05$ \\
\hline 20012 & $\begin{array}{l}10003 / \mathrm{G} / 2,10005 / \mathrm{G} / 15,10008 / \\
\mathrm{M} / 15,10008 / \mathrm{G} / 16,10009 / \mathrm{M} / 2\end{array}$ & 6 & 15 & $13: 34$ & $13: 49$ & $14: 19$ \\
\hline
\end{tabular}

Table 4-Break-up plan of inbound trains at technical station C

\begin{tabular}{||c|c|c|c|c|c|c|c||}
\hline $\begin{array}{c}\text { Inbound } \\
\text { train \# }\end{array}$ & $\begin{array}{c}\text { Inbound } \\
\text { time }\end{array}$ & $\begin{array}{c}\text { End time } \\
\text { of inbound } \\
\text { operation }\end{array}$ & Marshalling formation & $\begin{array}{c}\text { Break-up } \\
\text { order }\end{array}$ & $\begin{array}{c}\text { Start time of } \\
\text { break-up } \\
\text { operation }\end{array}$ & $\begin{array}{c}\text { End time } \\
\text { of break-up } \\
\text { operation }\end{array}$ & $\begin{array}{c}\text { Average } \\
\text { dwell time of } \\
\text { cars [min] }\end{array}$ \\
\hline \hline \multicolumn{7}{|c|}{ Remaining cars at the end of the previous stage--H/26,c/15 } & $13: 19$ \\
\hline 11001 & $12: 49$ & $13: 19$ & $\mathrm{O} / 29, \mathrm{~B} / 19$ & 1 & $13: 49$ \\
\hline 11002 & $13: 00$ & $13: 30$ & $\mathrm{O} / 21, \mathrm{~A} / 21, \mathrm{~B} / 10$ & 2 & $13: 49$ & $14: 19$ \\
\hline 11003 & $13: 21$ & $13: 51$ & $\mathrm{D} / 19, \mathrm{G} / 31$ & 3 & $14: 19$ & $14: 49$ \\
\hline 11004 & $14: 20$ & $14: 50$ & $\mathrm{D} / 13, \mathrm{M} / 19, \mathrm{E} / 9$ & 4 & $14: 50$ & $15: 20$ \\
\hline 11005 & $14: 27$ & $14: 57$ & $\mathrm{~A} / 10, \mathrm{O} / 23, \mathrm{I} / 17$ & 6 & $15: 50$ & $16: 20$ \\
\hline 11006 & $14: 31$ & $15: 01$ & $\mathrm{Q} / 20, \mathrm{~B} / 21$ & 5 & $15: 20$ & $15: 50$ \\
\hline 11007 & $15: 53$ & $16: 23$ & $\mathrm{~F} / 25, \mathrm{E} / 23, \mathrm{D} / 2, \mathrm{~N} / 18$ & 8 & $16: 23$ & $16: 53$ \\
\hline 11008 & $16: 06$ & $16: 36$ & $\mathrm{~A} / 19, \mathrm{D} / 20, \mathrm{I} / 13$ & 7 & $16: 53$ & $17: 08$ \\
\hline 11009 & $16: 15$ & $16: 45$ & $\mathrm{G} / 23, \mathrm{M} / 17$ & 9 & $17: 08$ & $17: 38$ \\
\hline 11010 & $16: 27$ & $16: 57$ & $\mathrm{~F} / 25, \mathrm{E} / 17$ & 11 & $18: 08$ & $18: 38$ \\
\hline 11011 & $16: 30$ & $17: 00$ & $\mathrm{~F} / 23, \mathrm{E} / 11, \mathrm{M} / 5$ & 12 & $18: 38$ & $19: 08$ \\
\hline 11012 & $16: 41$ & $17: 11$ & $\mathrm{M} / 15, \mathrm{~N} / 29$ & 10 & $17: 38$ & $18: 08$ \\
\hline
\end{tabular}


$\underline{\text { Yang Y, Wu X, Li H. Collaborative Optimization of Car-flow Organization for Freight Trains Based on Adjacent Technical Stations }}$

Table 5 - Marshalling plan for trains departing from technical station C

\begin{tabular}{|c|c|c|c|c|c|c|}
\hline $\begin{array}{l}\text { Outbound } \\
\text { train \# }\end{array}$ & Marshalling formation & $\begin{array}{l}\text { Marshalling } \\
\text { order }\end{array}$ & $\begin{array}{l}\text { Operating } \\
\text { time }\end{array}$ & $\begin{array}{c}\text { Start time of } \\
\text { marshalling } \\
\text { operation }\end{array}$ & $\begin{array}{l}\text { End time of } \\
\text { marshalling } \\
\text { operation }\end{array}$ & $\begin{array}{l}\text { Outbound } \\
\text { time }\end{array}$ \\
\hline 21001 & $11001 / \mathrm{O} / 29,11002 / \mathrm{O} / 21$ & 1 & 15 & $14: 19$ & $14: 34$ & $15: 04$ \\
\hline 21002 & $11001 / \mathrm{B} / 19,11002 / \mathrm{B} / 10,11006 / \mathrm{B} / 21$ & 2 & 15 & $14: 34$ & $14: 49$ & $15: 19$ \\
\hline 21003 & $11005 / \mathrm{I} / 17,11006 / \mathrm{Q} / 20,11008 / \mathrm{I} / 13$ & 4 & 15 & $17: 08$ & $17: 23$ & $17: 53$ \\
\hline 21004 & $11003 / \mathrm{G} / 31,11004 / \mathrm{M} / 19$ & 3 & 15 & $15: 20$ & $15: 35$ & $16: 05$ \\
\hline 21005 & H/Outage & - & 15 & - & - & - \\
\hline 21006 & $\begin{array}{c}11003 / \mathrm{D} / 19,11004 / \mathrm{D} / 13,11007 / \\
\mathrm{D} / 2,11008 / \mathrm{D} / 16\end{array}$ & 5 & 15 & $17: 23$ & $17: 38$ & $18: 08$ \\
\hline 21007 & $11004 / \mathrm{E} / 9,11007 / \mathrm{E} / 23,11007 / \mathrm{N} / 18$ & 7 & 15 & $17: 53$ & 18:08 & $18: 38$ \\
\hline 21008 & $11009 / \mathrm{M} / 17,11009 / \mathrm{G} / 23,11012 / \mathrm{M} / 10$ & 8 & 15 & 18:08 & $18: 13$ & $18: 43$ \\
\hline 21009 & $11007 / \mathrm{F} / 25,11010 / \mathrm{F} / 25$ & 9 & 15 & $18: 38$ & $18: 53$ & $19: 23$ \\
\hline 21010 & $11002 / \mathrm{A} / 21,11005 / \mathrm{A} / 10,11008 / \mathrm{A} / 19$ & 6 & 15 & $17: 38$ & $17: 53$ & $18: 23$ \\
\hline 21011 & $11010 / \mathrm{E} / 17,11011 / \mathrm{E} / 11,11012 / \mathrm{N} / 22$ & 10 & 15 & 19:08 & $19: 23$ & $19: 53$ \\
\hline 21012 & F/Outage & - & 15 & - & - & - \\
\hline
\end{tabular}

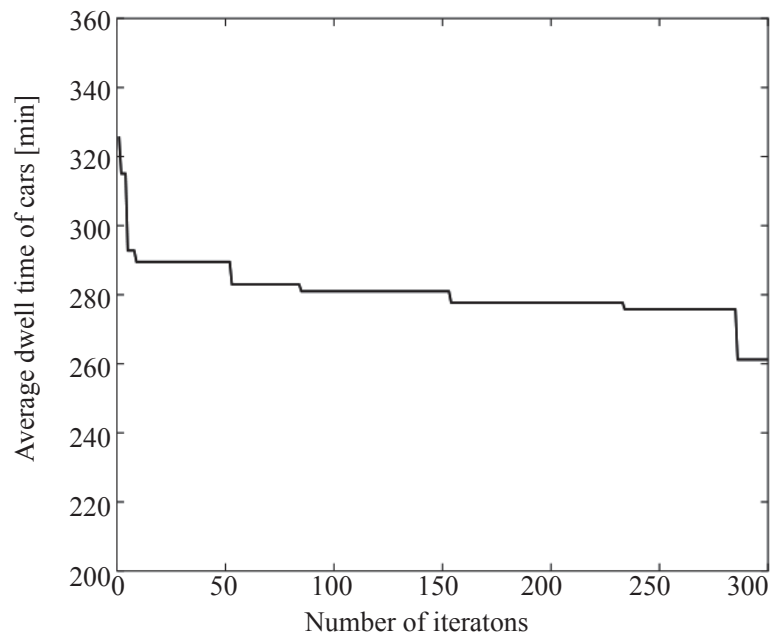

a) Technical station $B$

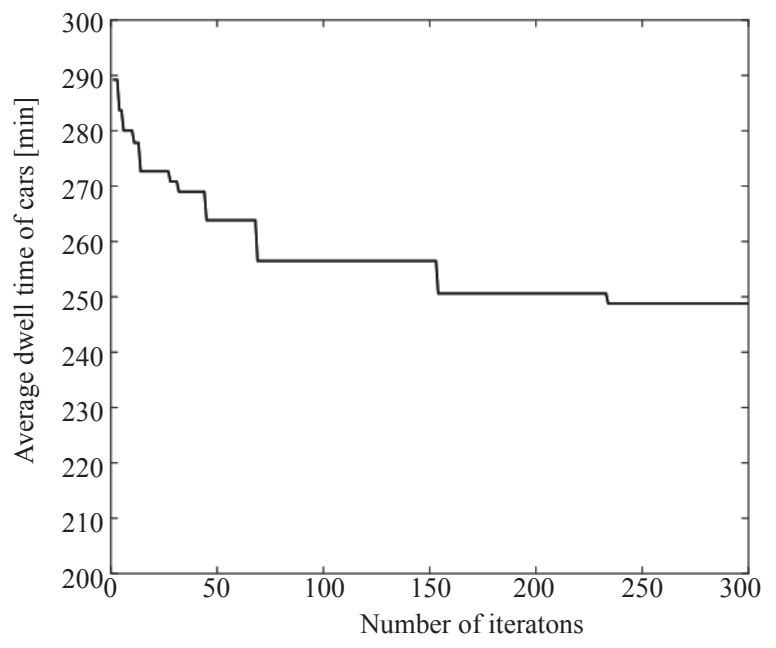

b) Technical station $C$

Figure 5 - Optimization diagram of dwell time of cars at technical stations $B$ and $C$

Table 6 - Outbound train marshalling plan at station B after collaborative optimization (changed)

\begin{tabular}{|c|c|c|c|c|c|c||}
\hline $\begin{array}{c}\text { Outbound } \\
\text { train \# }\end{array}$ & Marshalling formation & $\begin{array}{c}\text { Marshalling } \\
\text { order }\end{array}$ & $\begin{array}{c}\text { Operating } \\
\text { time }\end{array}$ & $\begin{array}{c}\text { Start time of } \\
\text { marshalling } \\
\text { operation }\end{array}$ & $\begin{array}{c}\text { End time of } \\
\text { marshalling } \\
\text { operation }\end{array}$ & $\begin{array}{c}\text { Outbound } \\
\text { time }\end{array}$ \\
\hline 20008 & $\begin{array}{c}10004 / \mathrm{C} / 9,10008 / \mathrm{H} / 14,10006 / \\
\mathrm{H} / 18,10006 / \mathrm{C} / 9\end{array}$ & 10 & 15 & $15: 19$ & $15: 34$ & $16: 04$ \\
\hline
\end{tabular}

Table 7 - Outbound train marshalling plan at station C after collaborative optimization (changed)

\begin{tabular}{||c|c|c|c|c|c|c||}
\hline $\begin{array}{c}\text { Outbound } \\
\text { train \# }\end{array}$ & Marshalling formation & $\begin{array}{c}\text { Marshalling } \\
\text { order }\end{array}$ & $\begin{array}{c}\text { Operating } \\
\text { time }\end{array}$ & $\begin{array}{c}\text { Start time of } \\
\text { marshalling } \\
\text { operation }\end{array}$ & $\begin{array}{c}\text { End time of } \\
\text { marshalling } \\
\text { operation }\end{array}$ & $\begin{array}{c}\text { Outbound } \\
\text { time }\end{array}$ \\
\hline \hline 21005 & remaining/H/26,20008/H/24 & 9 & 15 & $18: 13$ & $18: 28$ & $18: 58$ \\
\hline 21009 & $11007 / \mathrm{F} / 25,11010 / \mathrm{F} / 25$ & 10 & 15 & $18: 38$ & $18: 53$ & $19: 23$ \\
\hline 21011 & $11010 / \mathrm{E} / 17,11011 / \mathrm{E} / 11$, & 11 & 15 & $19: 08$ & $19: 23$ & $19: 53$ \\
\hline
\end{tabular}


technical station $\mathrm{C}$ is shown in Table 7. The average dwell time of the cars at technical station $\mathrm{C}$ is $240.84 \mathrm{~min}$, and the number of trains reaching the departure criteria is 11 .

\subsection{Discussion}

The comparison of the results of freight train car-flow organization between two adjacent technical stations and for a single technical station are shown in Table 8. Before the collaborative operation, the average dwell time of the cars at the two technical stations is $254.74 \mathrm{~min}$, and the number of trains reaching the departure criteria is 19 . After the collaborative operation, the average dwell time of the cars at the two technical stations is $249.84 \mathrm{~min}$, and the number of trains reaching the departure criteria is 21 . The results show that collaborative optimization of the car-flow organization for two adjacent technical stations allows average car dwell time savings of $4.9 \mathrm{~min}$ and facilitates two additional outbound trains reaching the departure criteria.

The average dwell time of cars at the station is shorter under a collaborative organization than when a single technical station is independently optimized. After the collaboration of the adjacent technical stations, one more outbound train achieves the departure criteria. Besides, compared to optimizing technical station B alone, the average dwell time of the cars at technical station B is $258.31 \mathrm{~min}$, which saves approximately $2 \%$ of the time. The results of this research are essential to improve the car-flow organization efficiency of the technical stations.

When the freight trains are assigned based on a single technical station, the destination of Train 20008 is only station $\mathrm{C}$ and there are only 26 cars, which does not satisfy the departure criteria. As the number of rail cars ready for departure is less than the critical value, Train 20008 cannot depart, which results in a "lost line" in the train timetable and increases the dwell time of cars at the station. After coordinating the operation of the two adjacent technical stations, the train destination changes to $\mathrm{C}$ and $\mathrm{H}$ because Train 20008 provides cars for station $\mathrm{C}$, thereby satisfying the departure criteria. By optimizing the train hump sequence at technical station B, Train 20008 can reach technical station C early to prepare for the car-flow organization.

The results show that the average dwell time of cars at technical station $\mathrm{C}$ after collaborative optimization is $240.84 \mathrm{~min}$, which also saves approximately $2 \%$ of the time and adds one outbound train reaching the departure criteria compared with optimizing technical station $\mathrm{B}$ alone. When considering only a single technical station for freight train carflow organization, Train 21005 at technical station $\mathrm{C}$ cannot reach the departure criteria because only 26 cars go to station $\mathrm{H}$, which extends the car dwell time at station C. Based on the above analysis, the application of the collaborative optimization model improves the capacity utilization of the technical stations.

\section{CONCLUSION}

A collaborative optimization model for the carflow organization of two adjacent technical stations is proposed in this paper, and the active scheduling method from the workpiece sequencing problem is used to adjust the hump sequence. Furthermore, this study uses the hybrid genetic algorithm to solve the model. Finally, an example is used to compare the car-flow organization results for a single technical station with those of two coordinated stations. The collaborative operation increases two outbound trains reaching the departure criteria and saves around $2 \%$ of the average dwell time of cars, which verifies the effectiveness of the proposed method. Although this method improves the efficiency of rail freight transportation, the time of the train break-up and marshalling operations is taken as a fixed value. In future research, the actual operation time can be

Table 8 -Analysis of car-flow organization results

\begin{tabular}{|c|c|c|c|c|c|c|c|}
\hline \multirow{2}{*}{$\begin{array}{l}\text { Technical } \\
\text { stations }\end{array}$} & \multicolumn{3}{|c|}{$\begin{array}{l}\text { Results of car-flow organization for a single } \\
\text { technical station }\end{array}$} & \multicolumn{3}{|c|}{$\begin{array}{l}\text { Results of collaborative optimization of car-flow } \\
\text { organization for two technical stations }\end{array}$} & \multirow{2}{*}{$\begin{array}{l}\text { Time } \\
\text { saved } \\
\text { [min] }\end{array}$} \\
\hline & $\begin{array}{l}\text { Number of } \\
\text { fully loaded } \\
\text { trains }\end{array}$ & $\begin{array}{c}\text { Number of } \\
\text { under-loaded } \\
\text { trains }\end{array}$ & $\begin{array}{l}\text { Average dwell } \\
\text { time of cars } \\
{[\mathrm{min}]}\end{array}$ & $\begin{array}{l}\text { Number of } \\
\text { fully loaded } \\
\text { trains }\end{array}$ & $\begin{array}{l}\text { Number of } \\
\text { under-loaded } \\
\text { trains }\end{array}$ & $\begin{array}{l}\text { Average dwell } \\
\text { time of cars } \\
{[\mathrm{min}]}\end{array}$ & \\
\hline B & 9 & 3 & 262.96 & 10 & 2 & 258.31 & 4.65 \\
\hline $\mathrm{C}$ & 10 & 2 & 246.01 & 11 & 1 & 240.84 & 5.17 \\
\hline Total & 19 & 5 & 254.74 & 21 & 3 & 249.84 & 4.9 \\
\hline
\end{tabular}


considered to make the study situation more realistic and multiple technical stations can be considered for the evaluation, instead of being limited to two.

\section{ACKNOWLEDGEMENT}

This work was supported by the National Key Research and Development Program of China (2018YFB1201402).

杨义静, 硕士 ${ }^{1}$

邮箱: 18120934@bjtu.edu.cn

武旭（通讯作者）, 博士 ${ }^{1}$

邮箱: wuxu@bjtu.edu.cn

李浩男, 硕士 ${ }^{1}$

邮箱: 19120838@bjtu.edu.cn

1 北京交通大学交通运输学院

北京市海淀区上园村3号, 中国, 北京

\section{基于相邻技术站的货物列车车流组织协同优化}

论文以最小化车辆在站平均停留时间为目标, 提 出了一种基于相邻技术站的货物列车车流组织协同 优化模型。为了解决车流组织问题, 采用了基于列 车优先级的解编顺序, 该顺序取决于相邻技术站内 的现有车辆情况。此外, 采用基于遗传算法和禁忌 搜索算法的元启发式算法对模型进行求解, 并引入 主动调度方法来提高算法效率。最后, 将该模型应 用于相邻技术站间的车流组织问题, 并将结果与单 技术站车流组织作业的结果进行比较。结果表明, 技术站间车流组织协同作业明显减少了车辆在站平 均停留时间, 从而提高了铁路设备的利用率。此 外, 结果表明, 混合遗传算法可以快速获得货物列 车的解编方案。

关键词: 协同优化; 车流组织; 遗传算法; 禁忌搜索算法; 主动调度

\section{REFERENCES}

[1] Ireland P, Case R, Fallis J, et al. The Canadian Pacific Railway Transforms Operations by Using Models to Develop Its Operating Plans. Interfaces. 2004;34(1): 5-14.

[2] Bontekoning Y, Priemus H. Breakthrough innovations in intermodal freight transport. Transportation Planning and Technology. 2004; 335-345.

[3] Wang CG. Research on the Model and Algorithm of Dynamic Car-Flow Allocating in a Marshalling Station. Journal of the China Railway Society. 2004;(01): 1-6.
[4] Yaghini M, Momeni M, Sarmadi M, et al. A fuzzy railroad blocking model with genetic algorithm solution approach for Iranian railways. Applied Mathematical Modelling. 2015;39(20): 6114-6125.

[5] Beloevi I, Milinkovi S, Ivi M, et al. Advanced evaluation of simultaneous train formation methods based on fuzzy compromise programing; 2019.

[6] Chen CS, Wang CG, Xue F, et al. Survey of Optimization of Train Formation Plan at Home and Abroad. Journal of the China Railway Society. 2012;34(02): 8-20.

[7] Zhang L. Design of Railway Express Transportation Products with Dedicated Lines for Passenger and Cargo Transportation. Logistics Technology. 2012;31(01): 86-88.

[8] Cao CX, Gao ZY, Li KP. Optimal rail container shipment planning problem in multimodal transportation. Engineering Optimization. 2012;44(9).

[9] Yaghini M, Foroughi A, Nadjari B. Solving railroad blocking problem using ant colony optimization algorithm. Applied Mathematical Modelling. 2011;35(12): 5579-5591.

[10] Calado M, Barros J, Nobre E, et al. A mixed integer programming approach for freight railcar distribution. Production. 2017; 27.

[11] Newton HN, Barnhart C, Vance PH. Constructing railroad blocking plans to minimize handling costs. Transportation Science. 1998;32(4): 330-345.

[12] Peter D, Denis K, Rybalchenko L, Muhitovs R. Optimization of train routes based on neuro-fuzzy modeling and genetic algorithms. Procedia Computer Science. 2019;149.

[13] Schindl D, Zufferey N. A learning tabu search for a truck allocation problem with linear and nonlinear cost components. Naval Research Logistics (NRL). 2015;62(1): $32-45$.

[14] Shafia MA, Sadjadi SJ, Jamili A, et al. The periodicity and robustness in a single-track train scheduling problem. Applied Soft Computing. 2012;12(1): 440-452.

[15] Liu SQ, Kozan E. Scheduling Trains with Priorities: A No-Wait Blocking Parallel-Machine Job-Shop Scheduling Model. Transportation Science. 2011;45(2).

[16] Lange J, Werner F. Approaches to modeling train scheduling problems as job-shop problems with blocking constraints. Journal of Scheduling; 2017.

[17] Zhang CY, Shao XY. Job Shop Scheduling Theory and Algorithm. Huazhong University of Science and Technology Press; 2014.

[18] Chang Y, Dong S. Study on post evaluation of high-speed railway based on FAHP and MATLAB simulation calculation. Tehnicki vjesnik/Technical Gazette. 2017;24(6). 